Emir. J. Agric. Sci. 2006. 18 (2): 01-10

http://www.cfa.uaeu.ac.ae/research/ejas.htm

\title{
Zinc sorption by some Torrifluvents soil of Sub-Saharian region South of Libya
}

\author{
R. A. Al-Tamimi \\ Soil \& Water Sci. Dept., College of Agric., Sebha Univ., P.O. Box 19332 , Libya
}

\begin{abstract}
Zinc sorption by four Torrifluvents soils from Sub-Saharian region, south of Libya was evaluated by equlibirating soil samples with concentrations of $\mathrm{Zn}$ covers a range of 0 to $320 \mathrm{ug} / \mathrm{ml}$. Effect of zinc carrier were also examined by using two carriers i.e. sulphate and EDTA. Results obtained show that all soils have high affinity for Zn sorption. Sorption isotherm of L (high affinity) type was noticed with zinc sulpate wheras S (low affinity) type was noticed with EDTA. Curviline relation between sorped zinc and zinc concentration in solution was proved by excellent fit of sorption to Frundlich equation. High mean values for sorption coefficient were noticed with sulphate (2.658) compared to EDTA carriers (0.350), While low mean value for regression coefficient $(1 / \mathrm{n})$ for mineral carrier $(0.354)$ was found compared to organic carrier (1.376). Sorption coefficient were significantly correlated with clay, silt, carbonate and organic matter contents in case of sulphate carrier only. While negatively correlated with carbonate and organic matter contents when EDTA was used.
\end{abstract}

Keywords: Freundlich equation, Langmuire equation, sandy soils, sorption, Temkin equation, Zn-sulphate, and Zn-EDTA .

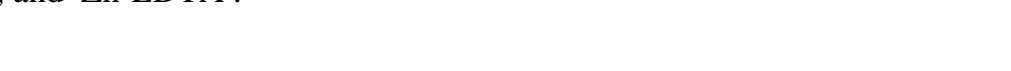

ر.ع. التميمي

\section{قصم التربة والميله،كلية الزراعة، جامسقسبها، ليبيا}

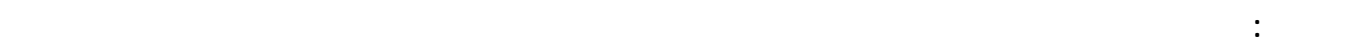

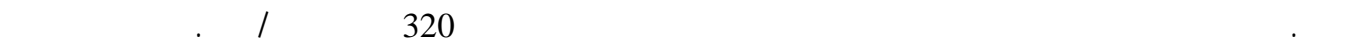

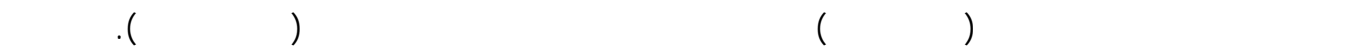

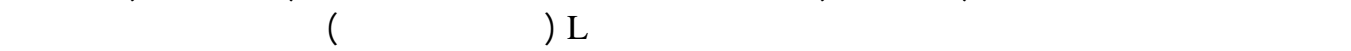

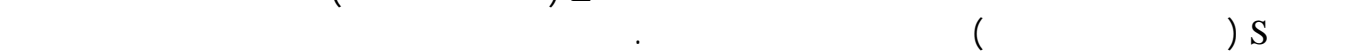

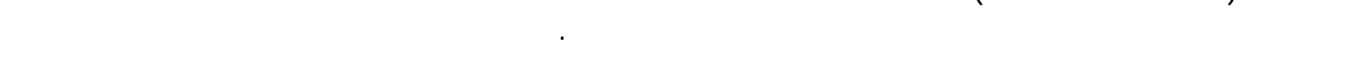

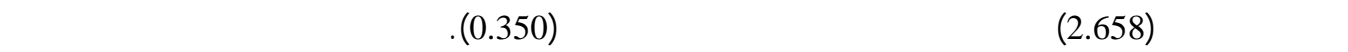

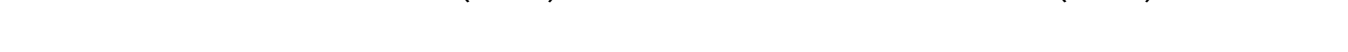

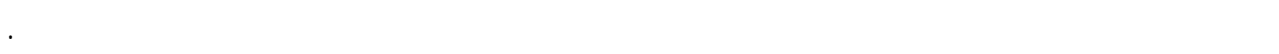

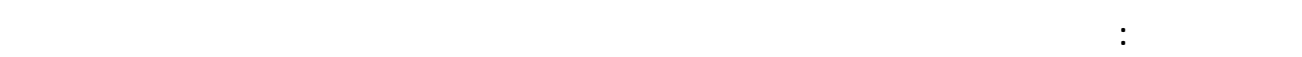
فرويندلخ، معادلة لنكمير.

\section{Intoduction}

Zinc is known as essential micronutrient for plant and haevy metal contaminant. Its sorption by soil is important in understanding its soil chemistry. Which is in turn important for agricultural and environmental purpose, by determining their availability to plant and their movment through soil. Zinc supplying power of soil, extraction by leaching and uptake by plant roots depending essentially on the amount of zinc present at sorption sites, (Sidhu et al., 1977; Joshi et al., 1983). Jurinak and Bauer (1956) explained that there are two types of zinc sorption; non-specific sorption which occurred as a result of electrical attraction by active surface sites, and specific sorption which occurred as strong chemical bond at nonorganic soil colloidal surfaces. In the later type of sorption, metal ion replace $\mathrm{O}^{-2}$ and $\mathrm{OH}^{-1}$ ions in inter crystal structure of oxides and hydroxides (Shuman, 1977; Kalbaski et al., 1978). Zinc may be irreversibly fixed by clay through 
isomorphus substitutions or solid-state diffusion into the crystal structure of layer silicates (Adriano, 1986).

Zinc sorption by soils can be influenced by; soil reaction (Lindsay, 1979; Chatterjee and Mandal, 1985; Romkens and Salomons,1998; Catlett et al., 2002; Dahiya, et al, 2005), clay content (Fahad,1988; Razaq et al. 1993; Dahiya, et al., 2005) , clay minerals type (Reddy and Perkins, 1974; Dahiya, et al., 2005), organic matter (Choudhari and Dhir, 1983; Falatah and Sheta, 1999; Catlett, et al., 2002; Dahiya, et al., 2005), total carbonate and active carbonate content (Sakal, et al. 1985; Fahad, 1988; Rahi, et.al. 1990; Al-Kaysi, 2000), amount of zinc applied and zinc carrier (Norvell, 1977; Al-Ameri, 2001; Obrador et al., 2003). Zinc sorption may also be affected by chemical composition of soil solution (Wang and Dustin, 2005) , ionic strength and complex formation with inorganic ligands in soil solution ( Mattigod and Sposito, 1977 ). Al-Hadethi et al. (2001) mentioned that extractable $\mathrm{Zn}$ recoverd from the added were negatively correlated with clay content, CEC, $\mathrm{CaCO}_{3}$, soluble calcium, and soluble magnesium. Zinc solubility also controlled by other reactions in soil such as mineral precipitation or adsorption onto $\mathrm{Fe}$ or $\mathrm{Mn}$ oxides (Catlett et al., 2002) and phosphate-Fe oxides interactions (Wang and Dustin, 2005). Continous application of large amount of zinc to soil may be caused possible accumulation of this element and potential harm to the environment, as zinc can be transported downward in soil and possibly deteriorate ground water quality. Downward movement of zinc in soil may be occurred under conditions of excess rainfall or irrigation water esspically in coarse-textured soils.

All soils in Sub-Saharian regions, south of Libya have been formed from alluvium material. Most of them classified as Torrifluvents and characterized by medium or coarse texture, neutral to alkaline reaction and low content of organic matter. Our prelimenery investigations show that zinc defficiency is widely dispersed in crops produced in these regions. Studies dealing with chemistry of zinc in soils of these regions are very scarce. So this study was carried out to explore zinc sorption in four Torrifluvents soils from these regions using two zinc carriers.

\section{Materials and Methods}

Four soil samples from surface layer (0$30 \mathrm{~cm}$ ) of some cultivated fields of Maknussa agricultuer project, in SubSaharian region, south of Libya, were obtained. All studied soils classified as Torrifluvents. Before use, the soil samples were air dried and ground to pass through 2-mm sieve. Particle size analysis was carried out using pipet method. Organic matter by modified Walkley-Black method, electrical conductivity and $\mathrm{pH}$, in soil paste extract, by conductometery and potontiometery respectively, total calcium carbonate equvielent by acid-neutralization method. All these analysis carried out as were described in Page et al. (1982). Available zinc was extracted by DTPA according to method proposed by Lindsay and Norvell (1978). Table 1 reported particle size distribution and some chemical characteristics of the studied soils. Sorption isotherm of $\mathrm{Zn}$ were determined by equalibrating $2 \mathrm{~g}$ soil in $70 \mathrm{ml}$ plastic tube with $50 \mathrm{ml}$ solution of $\mathrm{Zn}$. Zinc equilibrating solution concentration were; $0,10,20,40,80,160$, and 320 ug $\mathrm{ml}^{-1}$ as $\mathrm{ZnSO}_{4} \cdot 7 \mathrm{H}_{2} \mathrm{O}$ or Zn-EDTA. All solutions were adjusted to $\mathrm{pH} 7$ before used. Tubes were stoppered and placed in reciprocating shaker and shaken for $1 \mathrm{hr}$ at a speeding rate enough to keep the soil particles in suspenstion. Samples then incubated for additional $23 \mathrm{hrs}$ at $25{ }^{\circ} \mathrm{C}$. After the equilibration time, the tubes were centrifuged and the supernatant then filtered. The filtrate was reserved for 
Emir. J. Agric. Sci. 2006. 18 (2): 01-10

http://www.cfa.uaeu.ac.ae/research/ejas.htm

determining Zn. Zinc was determined by using atomic absorption spectrophotometer. The amount of metal sorbed was calculated by subtracting the amount of metal remaining in the equilibrium solution from the initially added. Three physicochemical equations were used to characterize zinc sorption these are; Langmuir equation (X/C $=\mathrm{Kb}$ $\mathrm{KX})$, Freundlich equation $\left(\log \mathrm{X}=\log \mathrm{K}_{\mathrm{f}}\right.$ $+1 / n \log C)$ and Temkin equation $(X=$
$\mathrm{K}_{\mathrm{t}}+\mathrm{B} \ln \mathrm{C}$ ), where $\mathrm{C}=$ concentration of zinc ion in equlibrating solution, $\mathrm{X}=$ quantity of sorbed zinc ion ; $\mathrm{K}, \mathrm{K}_{\mathrm{f}}, \mathrm{K}_{\mathrm{t}}$ constant ( $\mathrm{k}$ constant releated to binding strength according to Langmuir equation) and $\mathrm{b}, \mathrm{B}, \mathrm{n}$ constant $\mathrm{b}=$ maximum sorption according to Langmuir equation). Statistical parameters were used to choose most suitable equation characterize zinc sorption.

Table 1. Some physical and chemical characteristics of the soil used.

\begin{tabular}{|c|c|c|c|c|c|c|c|c|c|}
\hline \multirow{2}{*}{$\begin{array}{l}\text { Field } \\
\text { No. }\end{array}$} & \multirow{2}{*}{$\begin{array}{c}\mathrm{EC} \\
\mathrm{dS} \mathrm{m^{-1 }}\end{array}$} & \multirow[t]{2}{*}{$\mathrm{pH}$} & \multirow{2}{*}{$\begin{array}{c}\text { Zn-DTPA } \\
\text { mg kg }^{-1}\end{array}$} & \multicolumn{5}{|c|}{$\mathrm{g} \mathrm{kg}^{-1}$} & \multirow[t]{2}{*}{ Texture } \\
\hline & & & & O.M & $\mathrm{CaCO}_{3}$ & Clay & Silt & Sand & \\
\hline 7 & 1.19 & 8.58 & 0.40 & 17.0 & 57 & 80 & 81 & 839 & Loamy sand \\
\hline 12 & 2.12 & 8.25 & 0.44 & 11.0 & 56 & 121 & 153 & 726 & Sandy loam \\
\hline 31 & 0.76 & 8.34 & 0.36 & 5.6 & 17.5 & 49 & 48 & 903 & Sand \\
\hline 60 & 0.68 & 8.34 & 0.33 & 3.3 & 19 & 40 & 41 & 919 & Sand \\
\hline
\end{tabular}

\section{Results and Discussion}

All soils used showed a high sorption capacity at low concentration of zinc added ( $0-80 \mathrm{ppm}$ ) as $\mathrm{ZnSO}_{4} \cdot 7 \mathrm{H}_{2} \mathrm{O}$. A sharp increase in the amount sorped was found as the concentration of Zn initialy added increased from 0 to $80 \mathrm{ppm}$. Continuous increase in the amount of sorped Zn with increasing concentration of the added was noticed by all soils, but with decreasing percent (Table 2). This clearley indicates the high ability of these soils to retain $\mathrm{Zn}$. While, the amount and percent of sorbed zinc added as ZnEDTA were low at low levels of addition and increased with increasing concentration of addition (Table 2). Sorption isotherms of $\mathrm{Zn}$ added as zinc sulfate for soils used are presented in Figure 1 . The L type (high affinity type) of sorption isotherms for all soils indicates the high affinity of these soils for Zn. Zinc sorption show curvilinear relation with its concentration in equlibrium solution within the range 5$30 \mathrm{ppm}$. This explained that reddy sorption sites were decreased. High increment in the sorped amount with incresing the concentration of the added Zn from 160 to $320 \mathrm{ppm}$ indicate that this concentration was not large enough to saturation stage for all soils. Amount of Zn sorped by soils, as indicated by the position of sorption isotherms, was in the order: soil $12>$ soil $7>$ soil $31>$ soil 60 . This order of sorption was significantly correlated with clay, silt, calcium carbonate and organic matter contents (Table 3). This reslut was in agreement with the result of Choudhari and Dhir (1983); Razaq et al. (1993) and Falatah and Sheta (1999). 
Table 2. Amount of sorped zinc in the studied soils.

\begin{tabular}{ccccccccc}
\hline $\begin{array}{c}\text { Conc. Of } \\
\text { added Zn ug } \\
\text { ml }^{-1}\end{array}$ & \multicolumn{7}{c}{ Sorped amount of Zn from the added ( \%) } \\
& \multicolumn{2}{c}{ Soil 7 } & \multicolumn{2}{c}{ Soil 12 } & \multicolumn{2}{c}{ Soil 31 } & \multicolumn{2}{c}{ Soil 60 } \\
\cline { 2 - 10 } & ZnSO $_{4}$ & $\begin{array}{c}\text { Zn- } \\
\text { EDTA }\end{array}$ & ZnSO $_{4}$ & $\begin{array}{c}\text { Zn- } \\
\text { EDTA }\end{array}$ & ZnSO $_{4}$ & $\begin{array}{c}\text { Zn- } \\
\text { EDTA }\end{array}$ & ZnSO $_{4}$ & $\begin{array}{c}\text { Zn- } \\
\text { EDTA }\end{array}$ \\
\hline 10 & 99.2 & 12.9 & 99.8 & 17.5 & 99.0 & 20.3 & 98.8 & 6.7 \\
20 & 98.9 & 16.1 & 99.7 & 21.0 & 95.9 & 20.3 & 97.2 & 17.9 \\
40 & 95.2 & 17.4 & 98.9 & 19.5 & 86.1 & 20.7 & 87.2 & 12.5 \\
80 & 81.7 & 23.6 & 85.7 & 25.6 & 71.6 & 24.6 & 68.5 & 20.7 \\
160 & 63.3 & 33.6 & 80.2 & 34.1 & 57.5 & 33.8 & 53.4 & 33.9 \\
320 & 55.2 & 29.8 & 65.4 & 35.3 & 55.0 & 30.7 & 50.1 & 26.0 \\
\hline
\end{tabular}
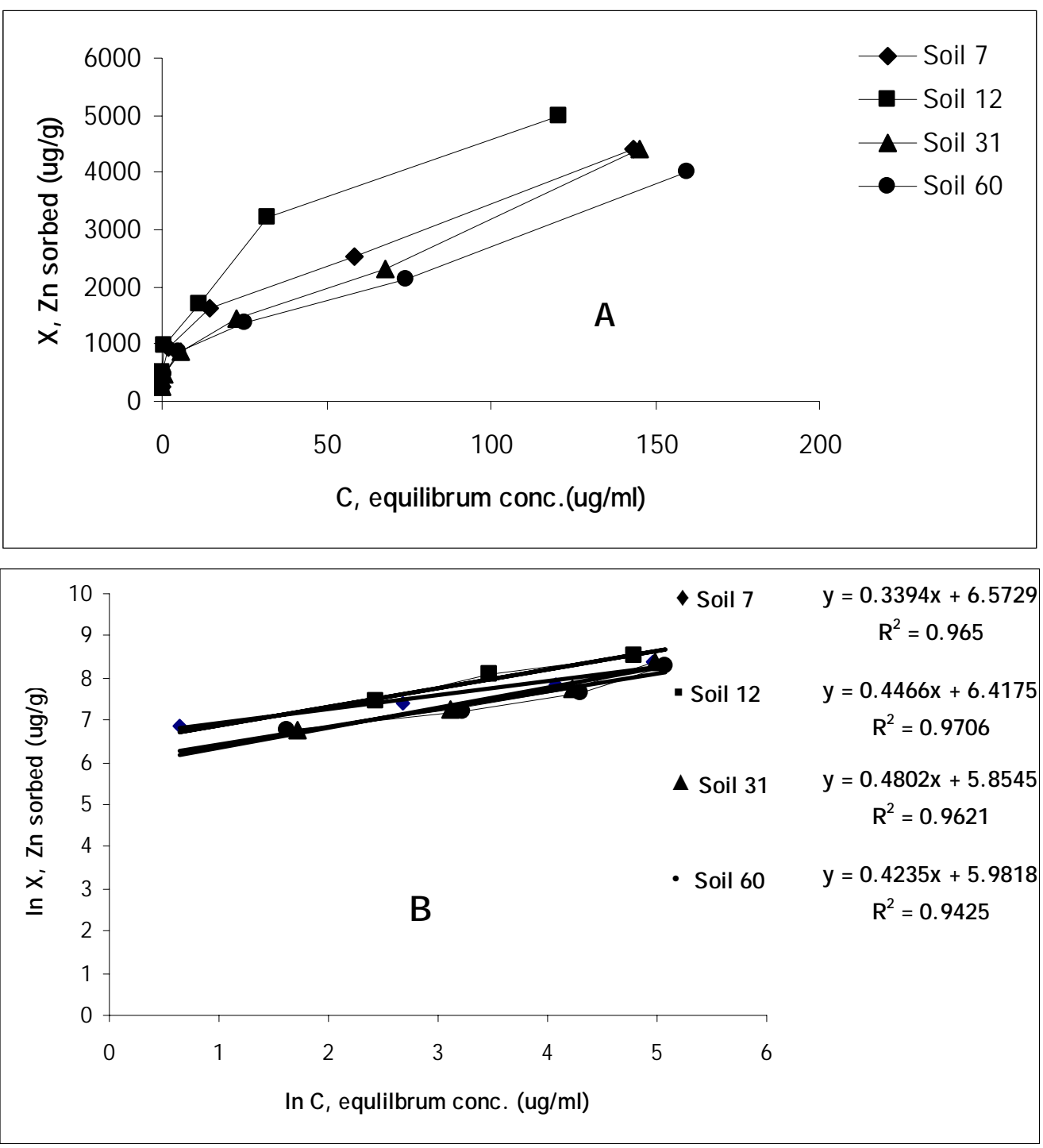

Figure 1. (A) Relationship between zinc sorped (X) and equlibrium concentration (C) when added as $\mathrm{ZnSO}_{4} \cdot 7 \mathrm{H}_{2} \mathrm{O}$, and (B) Sorption isotherm according to Freundlich eqution. 
Emir. J. Agric. Sci. 2006. 18 (2): 01-10

http://www.cfa.uaeu.ac.ae/research/ejas.htm

Table 3. Linear regrssion analysis of quantity of zinc sorped as affected by clay, carbonate, and organic matter contents.

\begin{tabular}{|c|c|c|c|}
\hline Soil parameter & Regression equation & Error df & Regression coefficient \\
\hline \multicolumn{4}{|c|}{$\mathrm{ZnSO}_{4}$} \\
\hline Clay & $Y=1278+57.5 X$ & 3 & $0.986 * *$ \\
\hline Silt & $Y=1365+40.9 X$ & 3 & $0.981 * *$ \\
\hline $\mathrm{CaCO}_{3}$ & $Y=1404+77.9 X$ & 3 & $0.805^{* *}$ \\
\hline $\mathrm{OM}$ & $Y=1510+200.6 X$ & 3 & $0.573^{* *}$ \\
\hline \multicolumn{4}{|c|}{ Zn-EDTA } \\
\hline Clay & $Y=751.5+5.5 X$ & 3 & $0.509 * *$ \\
\hline Silt & $Y=752.4+4.8 X$ & 3 & $0.627 * *$ \\
\hline $\mathrm{CaCO}_{3}$ & $Y=122.6+214.8 X$ & 3 & $0.09^{\mathrm{ns}}$ \\
\hline $\mathrm{OM}$ & $Y=331.9+369.6 X$ & 3 & $-0.325^{\mathrm{ns}}$ \\
\hline
\end{tabular}

Where; $\mathrm{Y}$ is the mean of adsorped quantity $\left(\mathrm{ug} \mathrm{g}^{-1}\right)$ and $\mathrm{X}$ is the percent of clay, $\mathrm{CaCO}_{3}$ or OM ; ns, not significant ${ }^{* *}$ significant at 0.01 level.
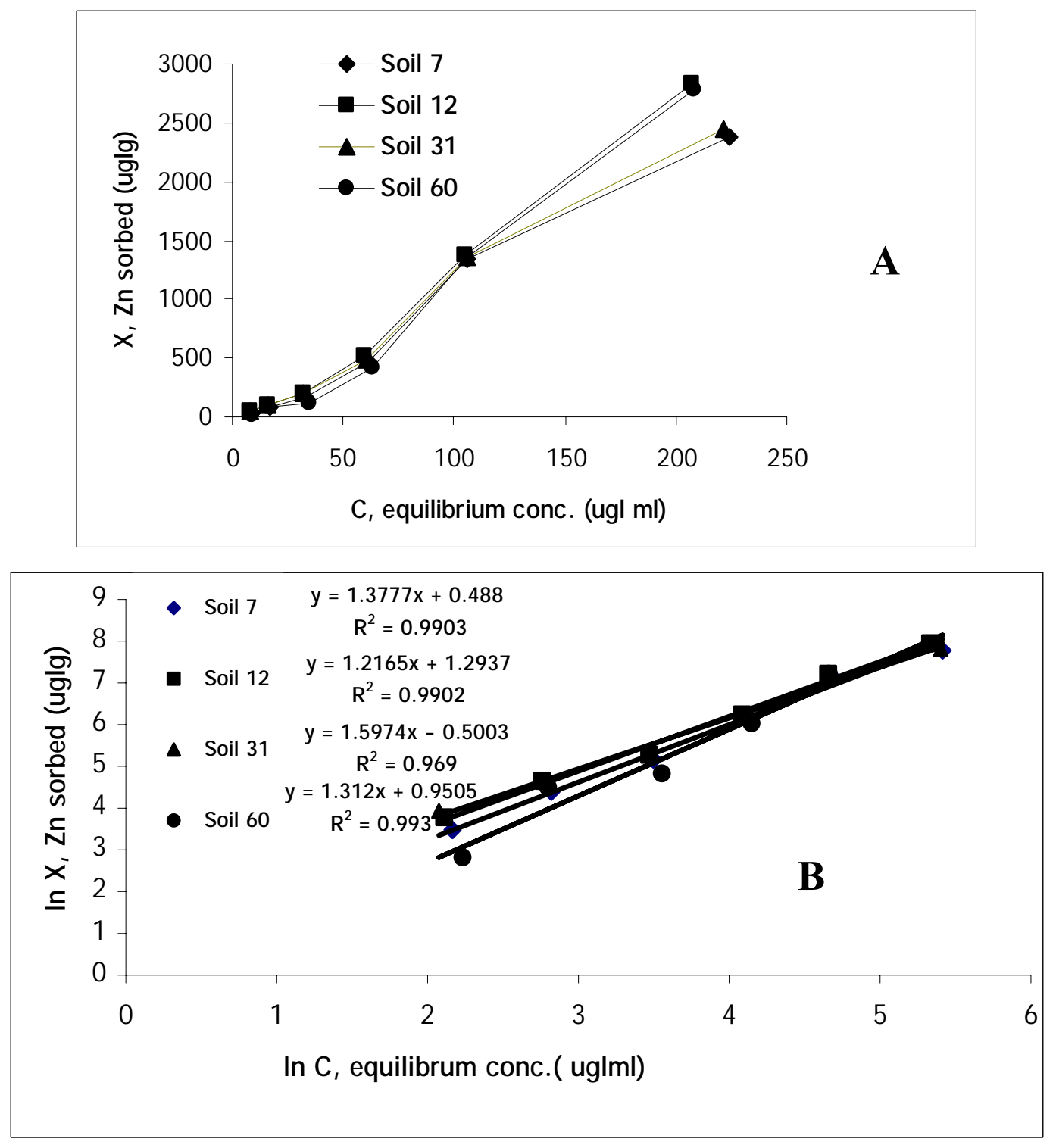

Figure 2. (A) Relationship between $\mathrm{Zn}$ sorbed $(\mathrm{X})$ and equilibrium concentration (C) when added as $\mathrm{Zn}$-EDTA, and (B) Sorption isotherm of $\mathrm{Zn}$ according to freundlich equation. 
Sorption isotherm of $\mathrm{Zn}$ added as $\mathrm{Zn-}$ EDTA presented in Figure 2. The $S$ type of sorption isotherm for all soils with ZnEDTA indicates low sorption affinity with low concentration. Continuous increase in the amount of Zn sorped also noticed with increasing added zinc. Sorption isotherm of $\mathrm{Zn}$ sorped from $\mathrm{Zn}$ EDTA for the studied soils was in the order : soil $12>$ soil $60>$ soil $31>$ soil 7. This indicate that reduction in the amount of sorped znic as a result of using chelate carier was different between soils used. This is may be attributed to differences in their chemical characteristics such as active carbonate, iron and manganes oxides and mineralogy. Sorption of zinc from ZnEDTA was not correlated with carbonate and organic matter contents, but significantly correlated with clay and silt contents (Table 3). This result indicated that carbonate and organic matter effect on zinc sorption were sufficieny inhibited by EDTA carrier .

Statistical parameters $\left(r^{2}, t, S E_{e}\right)$ were used to find the best fit of $\mathrm{Zn}$ sorption to the three physicochemical equations used. Results obtained indicate that Frundlich equation was excellent to describe the relation between $\mathrm{Zn}$ concentration in equlibrium solution and its sorption by soils. Frundlich equation has highest value of $r^{2}$ and $t$ in comparision to langmuir and temkin equations (Table 4). The excellent fit of Zn sorption to Frundlich equation was in agreement with Saeed and Fox (1979), El-Gundy et al. (1994), Falatah and Sheta (1999) and Al-Ameri (2001). The confirmation of Zn sorption to Frundlich equation suggest that sorption of this metal at high concentration in all soils used is curviline process (Shukla and Mittal, 1979, Elrashidi and O'Conner 1982) .

Frundlich equation's constant (Table 5) explain that soils vary in zinc sorption. Mean sorption coefficient (log $k_{f}$ ) for soils used were in the order: soil $12>$ soil $7>$ soil $60>$ soil 31 . This result are in good agrement with the clay, clay + silt and calcium carbonate contents. High values for $\log \mathrm{k}_{\mathrm{f}}$ was noticed with zinc sulphate in comparison with chelated zinc. Over all mean of $\log \mathrm{k}_{\mathrm{f}}$ with sulphate and EDTA carriers were 2.658 and 0.350 respectively. This clearly explain a reduction of 7.594 times in $\log$ $\mathrm{k}_{\mathrm{f}}$ with Zn-EDTA compared to Znsulphate carrier. Differences in $\log \mathrm{k}_{\mathrm{f}}$ are related to differences in properties and behaviour of the two carriers used, such as stability in soil system and ability to form precipitated minerals and components in soil solution. McBride (1989) indicated that some metal complexing ligands formed with EDTA suprpress metal adsorption. Thus sorped amount from each fertilizer and release constant of them will effectively affected (Lahav and Hochberg, 1975; Norvell, 1977 ).

Sgnificant correlation were found between sorption coefficient $\left(\log \mathrm{k}_{\mathrm{f}}\right)$ and content of clay $\left(0.663^{*}\right)$, silt $\left(0.655^{*}\right)$, calcium carbonate equvilent $\left(0.761^{*}\right)$ and organic matter $\left(0.516^{*}\right)$ when mineral carrier was used. Using organic carrier show low correlation between $\log \mathrm{k}_{\mathrm{f}}$ and the content of clay (0.420) and silt (0.394) and negative correlation with calcium carbonate equivelent $(-0.692 *)$ and organic matter $\left(-0.797^{* *}\right)$ (Table 6). This clearly explain the differences in sorption reduction value occured between the studied soils and confirmed the previous finding that organic carrier inhibit sufficiently zinc sorption by carbonate and organic matter in the studied soils.

Mean regression coefficient (1/n) value for mineral and organic zinc carriers were 0.354 and 1.376 respectively, which indicate that this factor was increased 3.887 times with using organic carrier compared to sulfate carrier. This confirmed the previous results found with $\log k_{\mathrm{f}}$. 
Emir. J. Agric. Sci. 2006. 18 (2): 01-10

http://www.cfa.uaeu.ac.ae/research/ejas.htm

\section{Conclusion}

In conclusions, zinc sorption in the studied soils highly correlated with clay, silt, calcium carbonate and organic matter contents. Effect of calcium carbonate and organic matter were highly inhibted by using EDTA as a carrier. This must be considerd when planning for fertlization program with zinc in these soils.

Table 4. Statistical parameters for zinc sorption according to physicochemical equations used in this study.

\begin{tabular}{|c|c|c|c|c|c|c|c|c|c|c|}
\hline \multirow{2}{*}{$\begin{array}{l}\text { Field } \\
\text { No. }\end{array}$} & \multirow{2}{*}{ Treatment } & \multicolumn{3}{|c|}{$\begin{array}{c}\text { Freundlich } \\
\text { Equation }\end{array}$} & \multicolumn{3}{|c|}{$\begin{array}{c}\text { Langmuir } \\
\text { Equation }\end{array}$} & \multicolumn{3}{|c|}{$\begin{array}{l}\text { Temkin } \\
\text { Equation }\end{array}$} \\
\hline & & $\mathbf{r}^{2}$ & t & $\mathbf{S . E _ { e }}$ & $\mathbf{r}^{2}$ & $\mathbf{t}$ & S.E $E_{e}$ & $\mathbf{r}^{2}$ & $\mathbf{t}$ & S.E $E_{e}$ \\
\hline \multirow{2}{*}{7} & $\mathrm{ZnSO}_{4}$ & 0.983 & 15.13 & 0.067 & 0.897 & 5.10 & 551.97 & 0.830 & 4.36 & 719.8 \\
\hline & Zn-EDTA & 0.990 & 20.18 & 0.079 & 0.625 & 2.58 & 2.433 & 0.815 & 4.19 & 451.8 \\
\hline \multirow{2}{*}{12} & $\mathrm{ZnSO}_{4}$ & 0.969 & 11.19 & 0.098 & 0.887 & 5.60 & 1790.4 & 0.828 & 4.39 & 886.4 \\
\hline & Zn-EDTA & 0.992 & 22.92 & 0.066 & 0.563 & 2.27 & 2.667 & 0.770 & 3.66 & 582.8 \\
\hline \multirow{2}{*}{31} & $\mathrm{ZnSO}_{4}$ & 0.968 & 10.98 & 0.092 & 0.989 & 19.20 & 112.79 & 0.694 & 3.01 & 994.0 \\
\hline & Zn-EDTA & 0.990 & 20.13 & 0.072 & 0.456 & 1.83 & 2.265 & 0.804 & 4.05 & 470.7 \\
\hline \multirow{2}{*}{60} & $\mathrm{ZnSO}_{4}$ & 0.966 & 10.72 & 0.088 & 0.963 & 10.25 & 180.15 & 0.713 & 3.15 & 823.8 \\
\hline & Zn-EDTA & 0.984 & 11.12 & 0.162 & 0.591 & 2.40 & 3.443 & 0.751 & 3.47 & 610.6 \\
\hline & mean & 0.981 & 15.63 & 0.089 & 0.746 & 6.15 & 330.76 & 0.775 & 3.78 & 693.1 \\
\hline
\end{tabular}

$\mathrm{r}^{2}:$ determination factor.

S.Ee : Standard error estimated .

Table 5. Constant of Frundlich equation for zinc sorption in the studid soils.

\begin{tabular}{|c|c|c|c|}
\hline Soil No. & Treatment & $\log K_{f}$ & $1 / \mathbf{n}$ \\
\hline \multirow{2}{*}{7} & $\mathrm{ZnSO} 4$ & 2.854 & 0.338 \\
\hline & Zn-EDTA & 0.212 & 1.377 \\
\hline \multicolumn{2}{|c|}{ Mean } & 1.533 & 0.857 \\
\hline \multirow{3}{*}{12} & $\mathrm{ZnSO} 4$ & 3.003 & 0.376 \\
\hline & Zn-EDTA & 0.413 & 1.312 \\
\hline & & 1.708 & 0.844 \\
\hline \multirow{2}{*}{31} & ZnSO4 & 2.055 & 0.358 \\
\hline & Zn-EDTA & 0.558 & 1.219 \\
\hline \multicolumn{2}{|c|}{ Mean } & 1.306 & 0.788 \\
\hline \multirow{2}{*}{60} & $\mathrm{ZnSO} 4$ & 2.720 & 0.343 \\
\hline & Zn-EDTA & 0.216 & 1.597 \\
\hline \multicolumn{2}{|c|}{ Mean } & 1.468 & 0.970 \\
\hline \multicolumn{2}{|c|}{ Mean With $\mathrm{ZnSO}_{4}$} & 2.658 & 0.354 \\
\hline \multicolumn{2}{|c|}{ Mean with Zn-EDTA } & 0.350 & 1.376 \\
\hline
\end{tabular}


Table 6. Correlation factor between sorption coefficient $\left(\log k_{f}\right)$ and some soil parameters.

\begin{tabular}{lcc}
\hline Soil parameter & \multicolumn{2}{c}{ Carrier } \\
\cline { 2 - 3 } & Sulphate & EDTA \\
\hline Clay & $0.663^{*}$ & 0.420 \\
Silt & $0.655^{*}$ & 0.394 \\
Carbonate & $0.761^{* *}$ & $-0.692^{*}$ \\
Organic matter & $0.516^{*}$ & $-0.797^{* *}$ \\
\hline$*, * *$ significant at 0.05 and 0.01 level respectively.
\end{tabular}

\section{Refrences}

Adriano, D. C. 1986. Trace elemments in the terrestrial environment. Springerverlag, New Yourk.

Al-Ameri, B. H. 2001. Behavior and efficiency of some zinc fertilizers in calcareous soils. M.Sc. Thesis. Agric. College, Univ. of Baghdad, Iraq.(in Arabic).

Al-Hadethi, A. A., J. K. Al-Uqaili and A. K. Abbas. 2001. Relationship between extractable $\mathrm{Zn}$ and plant $\mathrm{Zn}$ in calcareous soils. Dirasat J. Agric.Sci. 28(1): 24-32.

Al-Kaysi, S. Ch. 2000. Effect of physical and chemical properties of carbonate minerals in some Iraqi soils in zinc fixation. 1: Properties of carbonate minerals. Iraqi J. Agric. Sci. 30 (2): 53-72. (in Arabic).

Catlett, K. M., D. M. Heil; W. L. Lindsay and M. H. Ebinger. 2002. Soil chemical properties controlling Zn availability in eighteen colorado soil. Soil Sci. Soc. Am. J. 66: 1182-1189.

Chatterjee, A. K. and L. N. Mandal. 1985. Adsorption and desorption of zinc in soils of different physicochemical characters. J. Indian Soc. Soil Sci. 33:669-671.

Choudhari, J. S. and R. P. Dhir. 1983. Zinc adsorption by arid soil. Clays Clay Res. 2:52-56.
Dahiya, S., A V. Shanwal and H. A. G. Hedge. 2005. Studies on the sorption and desorption characteristics of $\mathrm{Zn}$ (II) on the surface soils of nuclear power plants sites in India using a radiotracer technique. Chemosphare 60 (9): 1253-1261.

El-Gundy, M. M., H. H. Hassona, M. F. Abdel-Sabour and R. A. S. Zalalu. 1994. Zinc sorption and desorption of some Egyptian shales. Egypt. J. Soil Sci. 34:389-401.

Elrashidi, M. M. and G. A. O'Connor. 1982. Influence of solution composition on sorption of zinc by soils. Soil Sci. Soc. Am. J. 46: 11531158.

Fahad, A. A. 1988. Fate of zinc applied to calcareous soil using ${ }^{65} \mathrm{Zn}$ as tracer: 1. Fractionation with time. Arid Soil Res. Rehabilitation. 2: 217-225.

Falatah, A. M. and A. S. Sheta. 1999. Influence of dissolved organic carbon and initial moisture on zinc sorption by two arid soils. Arid Soil Res. \& Rehabiltation. 13(2):133-144.

Joshi, D. C., B. K. Sharma and R. P. Dhir. 1983. Studies on the adsorption of $\mathrm{Zn}$ by fine textured alluvial soils of arid Rajasthan. Clay Res. 2: 39-45.

Jurinak, J. J. and N. Bauer. 1956. Thermodynamics of zinc adsorption on calcite, dolomite and magnesite 
Emir. J. Agric. Sci. 2006. 18 (2): 01-10

http://www.cfa.uaeu.ac.ae/research/ejas.htm

type minerals. Soil Sci. Soc. Am. Proc. 20:466-471.

Kalbasi, M., G. J. Racz and L. A. LowenRudgers. 1978. Mechanism of zinc adsorption by iron and aluminum. Soil Sci. Soc. Am. J. 39: 464-470.

Lahav, N. and M. Hochberg. 1975. Kinetics of fixation of iron and zinc applied as Fe-EDTA , Fe-HDDHA and Zn-EDTA in the soil. Soil Sci. Soc. Am. Proc. 39:55-58.

Lindsay, W. L. 1979. Zinc, In: Chemical Equilibria in Soils. pp. 211-220. John Willey \& Sons. Inc. New York.

Lindsay, W. L. and W. A. Norvell. 1978. Development of a DTPA soil test for zinc, iron, manganese and copper. Soil Sci. Soc. Am. J. 42:421-428.

Mattigod, S. V. and G. Sposito. 1977. Estimated association constants for some complex of trace metals with inorganic ligands. Soil Sci. Soc. Am. J. 41:1092-1097.

McBride, M. B. 1989. Reactions controlling heavy metals solubility in soils. Adv. Soil Sci.10:1-56.

Norvell, W. A. 1977. Equilibria of Metal Chelates in Soil Solution. In: Mortvedt, J. J; P. M.Giordano and W. L. Lindsay. (Eds). pp.115-138. Micronutrients In Agriculture. $3^{\text {rd }}$ ed. Am. Soil Sci. Soc., Inc. Madison, Wisconsin, USA.

Obrador, A., J. Novillo and M. Alvarez. 2003. Mobility and availability to plants of two zinc sources applied to calcareous soil. Soil Sci. Soc. Am. J. 67: 564-572.

Page, A. L., R. H. Miller and D. R. Keeney. 1982. Methods of Soil Analysis. Part 2. Chemical and
Microbiological Properties. Am Soc. Agron., Inc., Soil Sci. Soc. Am., Inc., Madison, Wisconsin, USA..

Rahi, H. S., I. I. Khuder and J. I. Juzeli. 1990. Zinc sorption in some calcareous soils of Erbil valley. Iraqi J. Agric. Sci. 21:150-162. (In Arabic).

Razaq, I. B., A. A. Fahad, A. A. AlHadethi, H. A. Tawfeek and J. S. Mahmmod. 1993. Adsorption and fractions distribution of $\mathrm{Mn}$ and $\mathrm{Zn}$ in response to salts, lime and clay content of soils of arid regions. Basrah J. Agric. Sci. 6(1):25-44.

Reddy, M. R. and Perkins, H. F. 1974. Fixation of zinc by clay minerals. Soil Sci. Soc. Am. J. 38:229-230.

Romkens, P. F. A. M. and W. Salomons. 1998. Cd, $\mathrm{Cu}$, and $\mathrm{Zn}$ solubility in arable and forest soils: Consequences of land use changes for metal mobility and risk assessment. Soil Sci. 163:859-871.

Saeed, M. and R. L. Fox. 1979. Relations between suspension $\mathrm{pH}$ and zinc solubility in acid and calcareous soils. Soil Sci. 124: 199-204.

Sakal, R., A. P. Singh, B. P. Singh, R. B. Sinha, S. V. Jha and S. P. Singh. 1985. Distribution of available micronutrient cations in calcareous soils as related to certain soil properties. J. Indian Soil Sci. 33: 672-675.

Shukla, U. C. and S. B. Mittal. 1979. Characterization of zinc adsorption in some soils of India. Soil Sci. Soc. Am. J. 43: 905-908.

Shuman, L. M. 1977. Adsorption of Zn by $\mathrm{Fe}$ and $\mathrm{Al}$ hydrous oxides as influenced by aging and $\mathrm{pH}$. Soil Sci. Soc. Am. J. 41:703-706. 
R. A. Al-Tamimi

Sidhu, A. S., N. S. Randhawa and M. K. Sinha. 1977 Adsorption and desorption of zinc in different soils. Soil Sci. 124:211-218.

Wang, Jim Jian and L. Dustin. 2005. Effect of ammonium, potassium and sodium cations and phosphate, nitrate and chloride anions on sorption and lability in selected acid and calcareous soils. Soil Sci. Soc. Am. J. 69:1036-1046. 